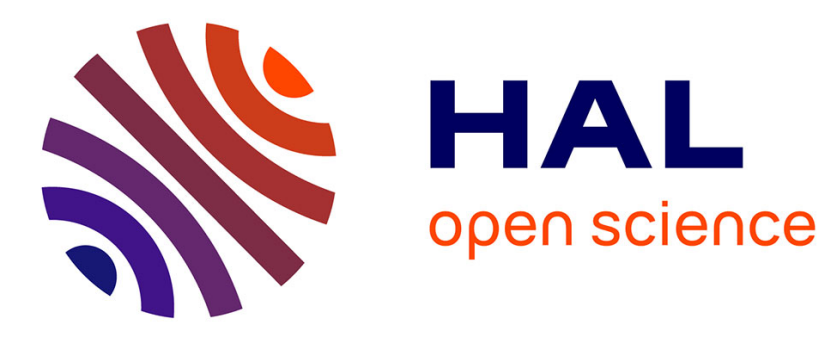

\title{
Dependency of Phytoprostane Fingerprints of Must and Wine on Viticulture and Enological Processes
}

\author{
Javier Marhuenda, Sonia Medina, Alexandra Díaz-Castro, Pedro \\ Martínez-Hernández, Simón Arina, Pilar Zafrilla, Juana Mulero, Camille \\ Oger, Jean-Marie Galano, Thierry Durand, et al.
}

\section{To cite this version:}

Javier Marhuenda, Sonia Medina, Alexandra Díaz-Castro, Pedro Martínez-Hernández, Simón Arina, et al.. Dependency of Phytoprostane Fingerprints of Must and Wine on Viticulture and Enological Processes. Journal of Agricultural and Food Chemistry, 2015, 63 (41), pp.9022-9028. 10.1021/acs.jafc.5b03365 . hal-02612407

\section{HAL Id: hal-02612407 \\ https://hal.science/hal-02612407}

Submitted on 3 Jun 2021

HAL is a multi-disciplinary open access archive for the deposit and dissemination of scientific research documents, whether they are published or not. The documents may come from teaching and research institutions in France or abroad, or from public or private research centers.
L'archive ouverte pluridisciplinaire HAL, est destinée au dépôt et à la diffusion de documents scientifiques de niveau recherche, publiés ou non, émanant des établissements d'enseignement et de recherche français ou étrangers, des laboratoires publics ou privés. 


\title{
Dependency of Phytoprostane Fingerprints of Must and Wine on Viticulture and Enological Processes
}

\author{
Javier Marhuenda, ${ }^{\dagger}, \perp$ Sonia Medina, ${ }^{\dagger}$ Alexandra Díaz-Castro, ${ }^{\dagger}$ Pedro Martínez-Hernández, ${ }^{\S}$ Simón Arina, ${ }^{\#}$ \\ Pilar Zafrilla, ${ }^{\perp}$ Juana Mulero, ${ }^{\perp}$ Camille Oger ${ }^{\Delta}$ Jean-Marie Galano, ${ }^{\Delta}$ Thierry Durand, ${ }^{\Delta}$ Federico Ferreres, ${ }^{\dagger}$ \\ and Angel Gil-Izquierdo*, ${ }^{\dagger}$ \\ ${ }^{\dagger}$ Research Group on Quality, Safety and Bioactivity of Plant Foods, Department of Food Science and Technology, CEBAS-CSIC,
Campus de Espinardo 25, Murcia, Spain
${ }^{\S}$ Clinical Analysis Service, University Hospital La Arrixaca, Murcia, Spain
${ }^{\#}$ Bodegas Baigorri S.L., Samaniego, País Vasco, Spain
${ }^{\perp}$ Food Science and Technology Department, Catholic University of Murcia (UCAM), Murcia, Spain
${ }^{\Delta}$ Institut des Biomolécules Max Mousseron, UMR 5247 CNRS-Universités Montpellier 1 \& Montpellier 2 - ENSCM, Montpellier,
France
}

ABSTRACT: Wine is one of the most consumed alcoholic beverages around the world. Red wine has demonstrated several benefits for health maintenance. One group of potential anti-inflammatory compounds is the phytoprostanes, oxidative degradation products of linolenic acid. The aim of the present study was to measure, for the first time, the phytoprostane content in wine and must by an UHPLC-QqQ-MS/MS method after solid-phase extraction. The data showed two predominant classes of phytoprostanes: $\mathrm{F}_{1^{-}}$and $\mathrm{D}_{1}$-phytoprostane series. In wines, the total phytoprostane concentration ranged from $134.1 \pm 2.3$ to $216.2 \pm 3.06 \mathrm{ng} / \mathrm{mL}$. Musts showed concentrations between $21.4 \pm 0.8$ and $447.1 \pm 15.8 \mathrm{ng} / \mathrm{mL}$. The vinification and aging procedures for the production of wine seem to influence the final phytoprostane levels in red wine and to modify the phytoprostane profile. The high concentrations observed and previous reports on anti-inflammatory effects of phytoprostanes make further research on the benefits of phytoprostanes more important.

KEYWORDS: phytoprostanes, oxidative stress, inflammation, red wine, lipid peroxidation

\section{INTRODUCTION}

Wine is a distinctive component of the Mediterranean diet, and one of the most consumed alcoholic beverages in Spain. Wine and grape berries have been demonstrated to provide several benefits for health maintenance. ${ }^{1}$

The main characteristic of wine proposed to benefit health is its ability to scavenge pro-oxidant species such as reactive oxygen species (ROS). The ROS are responsible for a high variety of dysfunctions, notably a dysfunction of the normal physiological function in plants and humans, leading to the oxidation of different molecules, such as amino acids, DNA, or lipids. $^{2}$ Lipid peroxidation products are formed by the nonenzymatic oxidation of lipids, such as prostanoids.

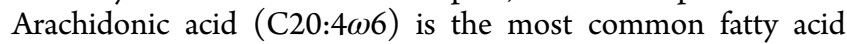
in mammals, and it can be converted into prostaglandins by cyclooxygenase, or it can be oxidized to isoprostanes (IsoPs) by free radical-mediated peroxidation. Linolenic acid (C18:3 $\omega 3$, ALA) is widely distributed in the plant kingdom and can be converted into jasmonic acid by enzymatic reactions. ${ }^{3}$ Imbusch and Mueller ${ }^{4}$ revealed a new class of dinor isoprostanes in plants, resulting from the nonenzymatic oxidation of ALA, which were named phytoprostanes (Figure 1). The effects of phytoprostanes depend on the stereoisomer. ${ }^{5}$ Nonenzymatic oxidation of ALA leads to two regioisomeric classes of phytoprostanes, and each of these includes 16 isomers, which are thought to be synthesized from membrane lipids of plant cells, such as IsoPs in mammals. ${ }^{3}$ Peroxidation of ALA results in
$G_{1}$-phytoprostane isomers, which can give rise to $D_{1^{-}}, E_{1^{-}}$, and $\mathrm{F}_{1}$-phytoprostanes. In turn, $\mathrm{D}_{1}$ and $\mathrm{E}_{1}$ rings can be converted into $\mathrm{J}_{1}$ and deoxy- $\mathrm{J}_{1}$ or $\mathrm{A}_{1}$ and $\mathrm{B}_{1}$ rings, respectively.

With regard to the beneficial effects of phytoprostanes, biological activities have been described in plants. ${ }^{3}$ In fact, $B_{1^{-}}$ and $\mathrm{A}_{1}$-phytoprostanes regulate gene expression in Arabidopsis thaliana and tobacco. ${ }^{6-8}$ In animal models, phytoprostanes have also demonstrated bioactive effects. For example, $\mathrm{A}_{1}$ - and $\mathrm{dJ}_{1}$-phytoprostanes, at similar concentration, showed antiinflammatory effects like those of $\mathrm{PGA}_{1}$ and $\mathrm{dPGJ}_{2}$. Moreover, $\mathrm{E}_{1}$-phytoprostane inhibits in vitro synthesis of dendritic cell interleukin-12 and interleukin-1. ${ }^{9,10}$ Concurrently, $\mathrm{E}_{1^{-}}$and $\mathrm{F}_{1^{-}}$ phytoprostanes were able to reduce the in vivo production of cytokine Th1 and Th2 profiles. ${ }^{11}$

Currently, our knowledge of phytoprostane quantitation and identification is limited to tobacco, the leaves of some plant species, and tomato. ${ }^{3}$ Previous studies have already reported the presence of different classes of phytoprostanes in vegetable and olive oils, particularly in linseed and soybean oils, as well as in aqueous pollen extracts. ${ }^{5,9,12}$ To the best of our knowledge, no reports about the phytoprostane content of red wine have been published. Therefore, grape, must, and the vinification 


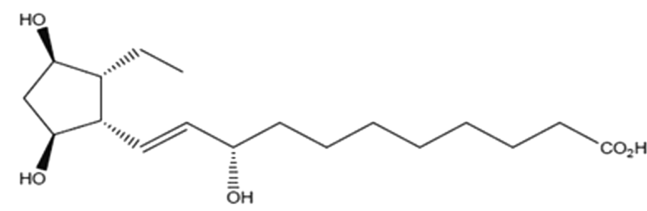

9- $F_{1 \mathrm{t}}$-phytoprostane<smiles>CC[C@H](O)/C=C/[C@H]1[C@H](O)C[C@@H](O)[C@@H]1CCCCCCCC(=O)O</smiles>

ent-16- $\mathrm{F}_{1 \mathrm{t}}-$ phytoprostane

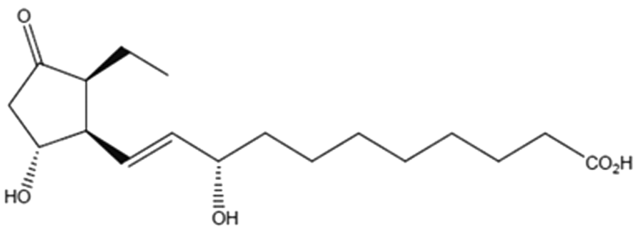

9-D $D_{1 \mathrm{t}}-$ phytoprostane<smiles>CC[C@H](O)/C=C/C1=C(CCCCCCC(=O)O)C(=O)CC1</smiles>

16- $B_{1}$-phytoprostane

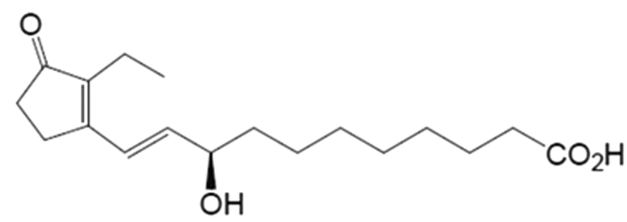

9-L L $_{1}$-phytoprostane

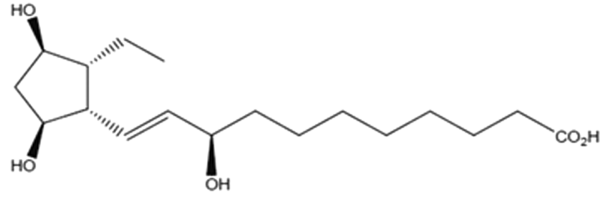

9-epi-9- $\mathrm{F}_{1 \mathrm{t}}-$ phytoprostane<smiles>CC[C@H](O)/C=C/[C@H]1[C@H](O)C[C@@H](O)[C@@H]1CCCCCCCC(=O)O</smiles>

ent-16-epi-16- $\mathrm{F}_{1 \mathrm{t}}$-phytoprostane

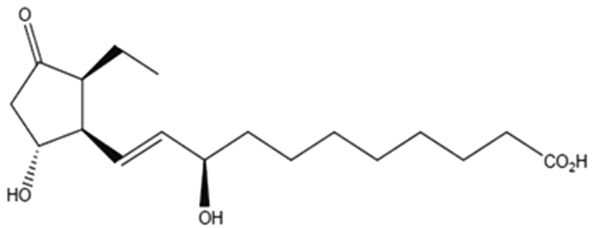

9-epi-9- $\mathrm{D}_{1 \mathrm{t}}-$ phytoprostane<smiles>CC[C@H](O)/C=C/C1=C(CCCCCCC(=O)O)C(=O)CC1</smiles>

ent-16- $B_{1}$-phytoprostane

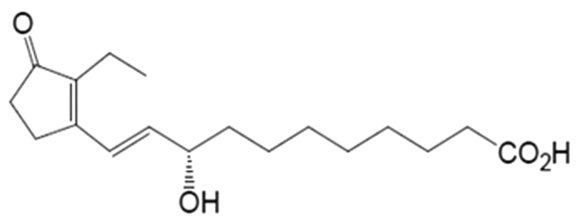

ent-9- $\mathrm{L}_{1}$-phytoprostane

Figure 1. Metabolites of the different families of phytoprostanes.

procedure, in relation to changes in the phytoprostane content of wine or must, is a wide field to explore. It is made even more important by taking into account that the scientific literature has highlighted phytoprostanes as a representative tool for measuring in vivo stress in plants. ${ }^{4,6}$ Phytoprostanes could also be of interest to wineries, to determine the oxidative status of their products and as a quality control in the winemaking process.

\section{MATERIALS AND METHODS}

Standards and Reagents. Phytoprostanes are very stable in their frozen form, they can remain unaltered for several years. Phytoprostane standards (9- $\mathrm{F}_{1 \mathrm{t}}$-phytoprostane (Phyto1), ent-16-epi16- $\mathrm{F}_{1 \mathrm{t}}$-phytoprostane + ent-16- $\mathrm{F}_{1 \mathrm{t}}$ - phytoprostane (Phyto2+3), 9-epi-9$\mathrm{D}_{1 \mathrm{t}}$-phytoprostane (Phyto4), 9- $\mathrm{D}_{1 \mathrm{t}}$ - phytoprostane (Phyto5), 16- $\mathrm{B}_{1^{-}}$ phytoprostane + ent-16- $\mathrm{B}_{1}$-phytoprostane (Phyto6+7), 9- $\mathrm{L}_{1}$-phytoprostane + ent-9- $\mathrm{L}_{1}$-phytoprostane (Phyto8+9)) were synthesized according to previous procedures. ${ }^{13-16}$

Solid-phase extraction (SPE) cartridge was Strata X-AW (100 mg/3 $\mathrm{mL}$ ) from Phenomenex (Torrance, CA, USA). Both butylated hydroxyanisole (BHA) and bis(2-hydroxyethyl)aminotris(hydroxymethyl)methane (BIS-TRIS) were purchased from SigmaAldrich (St. Louis, MO, USA). Methanol $(\mathrm{MeOH})$ was acquired from VWR (Fontenay-sous-Bois, France), acetonitrile was obtained from Merck (Darmstadt, Germany), and $n$-hexane was purchased from Panreac (Barcelona, Spain). All LC-MS grade solvents were obtained from J. T. Baker (Phillipsburg, NJ, USA). Water was treated in a MilliQ water purification system (Millipore, Bedford, MA, USA).

Red Wine Samples. Red wines were provided by Baigorri winery (Bodegas Baigorri S.A.U, Samaniego, Álava, Spain). Three different wines were selected to study different vinification and aging 
procedures. For correct maintenance, they were stored between 12 and $14{ }^{\circ} \mathrm{C}$ after bottling.

"Baigorri carbonic maceration 2010" wine (CMW) was made with a combination of tips of bunches from hand-harvested Tempranillo grapes. Before being fermented, the grapes were macerated for a long time. Short fermentations in stainless steel tanks were performed. No aging procedure was employed.

"Baigorri aged 2007" wine (AW) was manufactured using the tips of bunches of hand-harvested Tempranillo (90\%), Garnacha (5\%), and other native grape varieties (5\%). Long macerations and intracellular fermentations in stainless steel tanks were employed. Large oak barrels were employed during the 14 months of aging.

"Baigorri high expression 2010" wine (HEW) was made from handharvested Tempranillo grapes selected from very old ( $>50$ years) and low-yielding vineyards. For its long maceration and fermentation times, stainless steel tanks were used throughout the process. Large oak barrels were also employed during the 22 months of aging.

The alcoholic grades of CMW and AW were similar $\left(13.5^{\circ}\right)$, but that of HEW was slightly higher $\left(14^{\circ}\right)$.

Must Samples. The musts analyzed during the current study were stored at $-20{ }^{\circ} \mathrm{C}$ for 7 months after the harvest of the grapes, so that the fermentation process did not begin. They were the original grape juices used for the winemaking procedure of each wine. This allows elucidation of the effect of the winemaking process, by direct comparison of each must with its respective wine.

The must samples are referred to in the text as follows: CMM for the initial must of "Baigorri carbonic maceration" wine, AM for the initial must of "Baigorri aged 2010" wine, and HEM for the initial must of "Baigorri high expression 2010" wine.

The chemical compositions of the samples were quite similar. Total acidity values of must samples were 4.44, 5.81, and $6.58 \mathrm{~g} / \mathrm{L}$ for CMM, AM, and HEM, respectively. Finally, density values were 1102 , 1099, and 1100 , whereas $\mathrm{pH}$ values were $3.65,3.42$, and 3.52 for CMM, AM, and HEM, respectively.

Extraction of Phytoprostanes. For the analysis of phytoprostanes, their extraction from wines and musts was performed following the SPE method developed by Medina et al. ${ }^{17}$ and Collado-González et al., ${ }^{12}$ slightly modified for the wine matrix. A mixture of three different bottles of each wine was employed for the extraction. Strata $\mathrm{X}$-AW cartridges were employed for the SPE and were conditioned with $2 \mathrm{~mL}$ of methanol followed by $2 \mathrm{~mL}$ of Milli-Q water. After that, the cartridges were washed with $2 \mathrm{~mL}$ of water, $2 \mathrm{~mL}$ of methanol/ water $(1: 3, \mathrm{v} / \mathrm{v})$, and $2 \mathrm{~mL}$ of acetonitrile. Finally, the samples were eluted with $1 \mathrm{~mL}$ of methanol. The samples were brought to dryness under vacuum, reconstituted with $200 \mu \mathrm{L}$ of elution phases A:B (90:10, v/v), and filtered through a Millex HV13 $0.45 \mu \mathrm{m}$ membrane filter (Millipore, Bedford, MA, USA).

UHPLC-QqQ-MS/MS Analyses. Separation of the phytoprostanes present in the samples was performed using a UHPLC coupled to a 6460 QqQ-MS/MS (Agilent Technologies, Waldbronn, Germany), as previously described. ${ }^{12}$ Each sample was analyzed in triplicate. Chromatographic separation was carried out on a BEH $1562.1 \times$ $50 \mathrm{~mm}, 1.7 \mu \mathrm{m}, \mathrm{C}_{18}$ column (Waters, Milford, MA, USA). The column temperatures were $6{ }^{\circ} \mathrm{C}$ (left side) and $6{ }^{\circ} \mathrm{C}$ (right side). The mobile phases employed were solvent A (water/acetic acid (99.99:0.01, v/v)) and solvent B (methanol/acetic acid (99.99:0.01, v/v)). The elution was performed at a flow rate of $0.2 \mathrm{~mL} / \mathrm{min}$, using the following gradient profile: $60 \% \mathrm{~B}$ at $0 \mathrm{~min}, 62 \% \mathrm{~B}$ at $2 \mathrm{~min}, 62.5 \% \mathrm{~B}$ at $4 \mathrm{~min}$, reaching $65 \% \mathrm{~B}$ at $8 \mathrm{~min}$, and returning to the initial conditions at 8.01 min.

The MS analysis was applied in the multiple reaction monitoring (MRM) negative ESI mode. The ESI conditions and ion optics were as previously described. ${ }^{12}$ Data acquisition and processing were performed using MassHunter software, version B.04.00 (Agilent Technologies). The quantitation of phytoprostanes detected in the wines and musts was performed using authentic standards of $9-\mathrm{F}_{1 t^{-}}$ phytoprostane, ent-16-epi-16- $\mathrm{F}_{1 \mathrm{t}}$-phytoprostane, ent-16- $\mathrm{F}_{1 \mathrm{t}}$-phytoprostane, 9-epi-9- $\mathrm{D}_{1 \mathrm{t}}$-phytoprostane, 9- $\mathrm{D}_{1 \mathrm{t}}$-phytoprostane, 16- $\mathrm{B}_{1}$-phytoprostane, ent- $16-\mathrm{B}_{1}$-phytoprostane, $9-\mathrm{L}_{1}$-phytoprostane, and ent-9- $\mathrm{L}_{1}$ - phytoprostane. The synthetic isoprostane $\mathrm{d}_{4}-15-\mathrm{F}_{2 \mathrm{t}}-\mathrm{IsoP}$ (8-isoPGF ${ }_{2 \alpha^{-}}$ $\mathrm{d}_{4}$ ) was used as the internal standard.

Statistical Analysis. An analysis of variance (ANOVA; Duncan) was applied to establish significant differences between the means obtained for the different samples of wine and must. A probability value of $p<0.05$ was adopted as the criterion for significant differences. These analyses were performed with SPSS version 15 software (SPSS Inc., Chicago, IL, USA).

\section{RESULTS AND DISCUSSION}

Qualitative Analysis of Phytoprostanes. The individual phytoprostanes found in wines and musts are shown in Figure 2. Their identification was confirmed according to their molecular masses, the precursor ions $(\mathrm{m} / z 327.2$ and 307.2), the characteristic MS/MS fragmentation product ions, and the corresponding retention times. In contrast to prostaglandins, phytoprostanes are formed nonenzymatically as regio- and stereoisomeric mixtures. ${ }^{12}$ The phytoprostane profiles of the
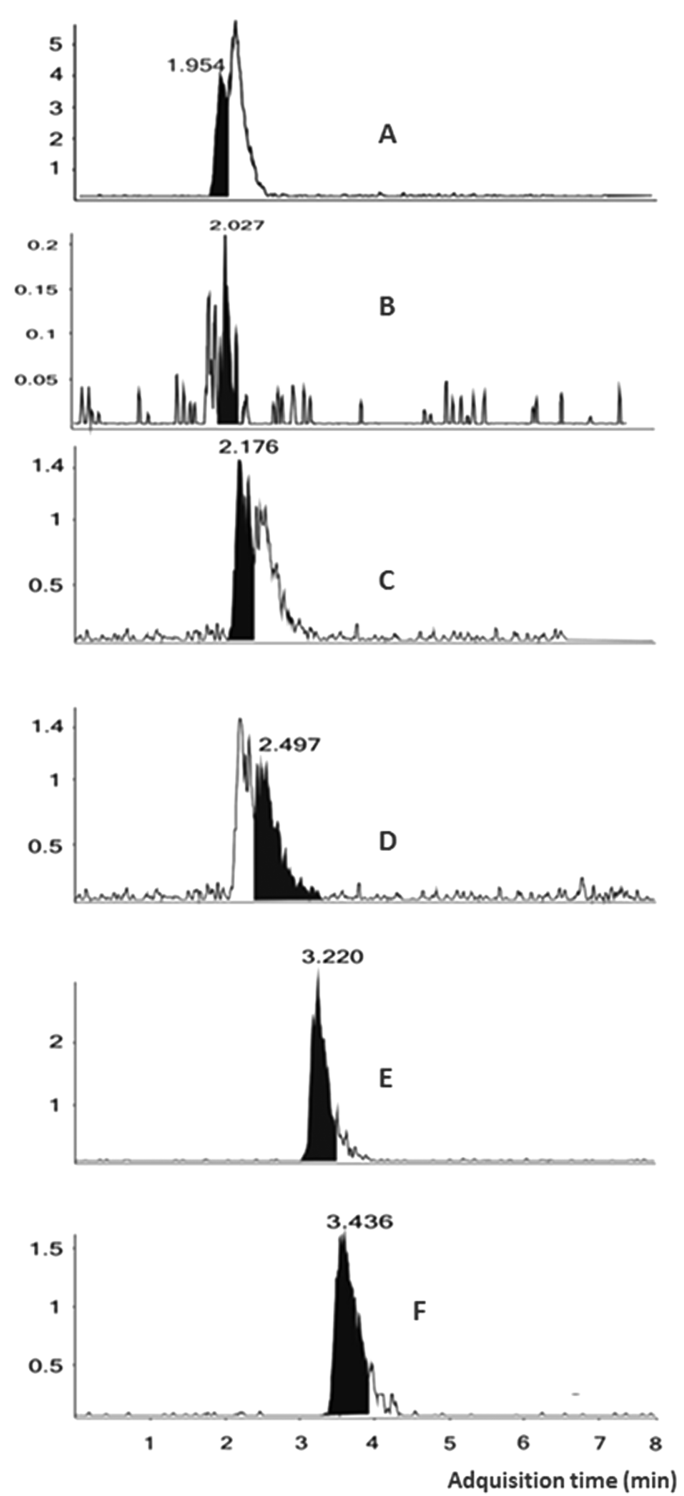

Figure 2. Phytoprostane chromatograms for CMW, measured by UPLC-MS/MS: (A) 9- $\mathrm{F}_{1 \mathrm{t}}$-phytoprostane; (B) ent-16-epi-16- $\mathrm{F}_{1 \mathrm{t}}{ }^{-}$

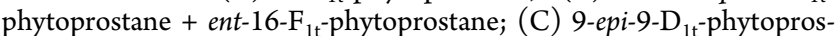
tane; (D) 9- $\mathrm{D}_{1 \mathrm{t}}$-phytoprostane; (E) 16- $\mathrm{B}_{1}$-phytoprostane + ent-16- $\mathrm{B}_{1^{-}}$

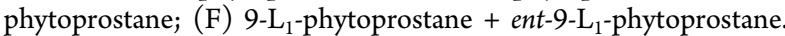


analyzed beverage samples indicate the presence in all samples of the 9 and 16 series of the $F_{1^{-}}$and $D_{1}$-classes of phytoprostanes. The B-series and L-series did not present a well standardized distribution among the different samples. In addition, only one wine (CMW) and one must (HEM) contained enantiomers of the racemic mixtures of $16-\mathrm{B}_{1^{-}}$and 9$\mathrm{L}_{1}$-phytoprostane (Phyto6+7 and Phyto8+9). It is important to emphasize that the analytical conditions employed in this study did not allow separation of the enantiomers of the racemic mixtures of $16-\mathrm{B}_{1}$-phytoprostane + ent-16- $\mathrm{B}_{1}$-phytoprostane and 9- $\mathrm{L}_{1}$-phytoprostane + ent-9- $\mathrm{L}_{1}$-phytoprostane. Therefore, both enantiomers of $\mathrm{L}$ - and B-series were quantitated together.

Four phytoprostanes were identified in all of the samples (the three wines and the three musts): Phyto1, Phyto2+3, Phyto4, and Phyto5.

Quantitative Analysis of Phytoprostanes. The concentrations of total free phytoprostanes are represented in Figure 3.

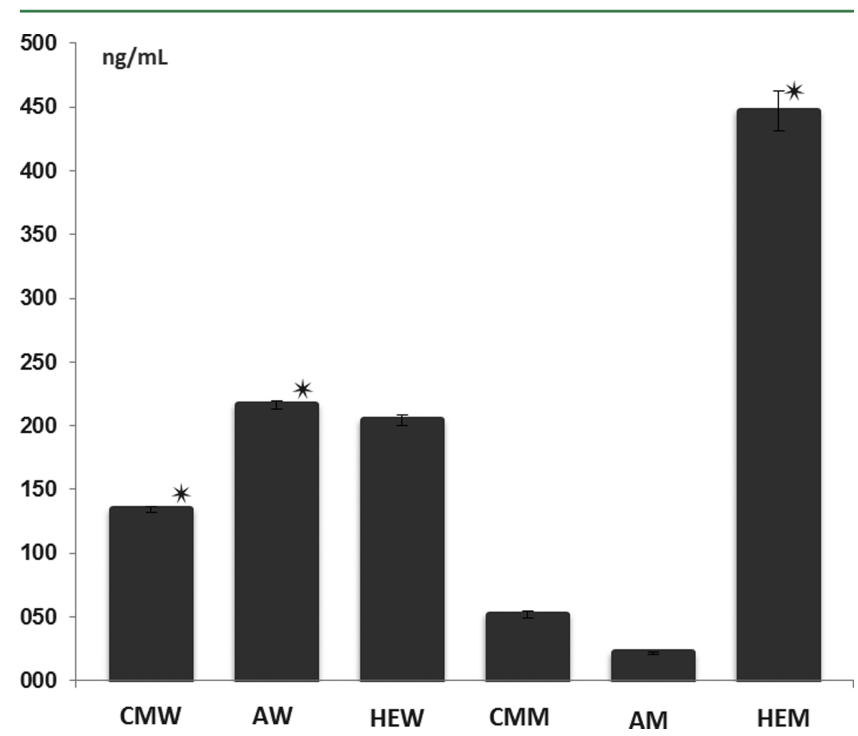

Figure 3. Concentrations of total phytoprostanes. CMW/CMM, wine/must with carbonic maceration; AW/AM, aged wine/must; HEW/HEM, high-expression wine/must.

This concentration varied widely among the three primary musts. In fact, no significant difference $(p>0.05)$ in the final concentration of total phytoprostanes was found when the primary must corresponding to carbonic maceration wine (CMM) $(48.9 \pm 2.6 \mathrm{ng} / \mathrm{mL})$ and the primary must of aged wine (AM) $(20.5 \pm 0.8 \mathrm{ng} / \mathrm{mL})$ were compared. However, the primary must of high-expression wine (HEM) had a significantly higher level $(p<0.01)$ of total phytoprostanes $(430.9 \pm 15.7 \mathrm{ng} / \mathrm{mL})$ than CMM or AM. As commented on above, HEM came from very old and low-yielding vineyards ( $>50$ years old), which are exposed to more stress factors than newer vineyards. ${ }^{18}$ This would probably lead to an increase in pro-oxidant reactive species and to the subsequent formation of phytoprostanes by lipid peroxidation of ALA. Consequently, differences in agronomic factors (vineyard age) could have contributed to the different concentrations of total phytoprostanes, compared to HEM, in the must from grapes grown in the new vineyards (CMM and AM).

In the three wine samples studied, the total phytoprostane concentration did not present a standardized range. Actually, the values did not vary $(p>0.05)$ between aged wine (AW) $(213.2 \pm 3.1 \mathrm{ng} / \mathrm{mL})$ and high-expression wine (HEW) $(199.8$ $\pm 4.2 \mathrm{ng} / \mathrm{mL}$ ), but the total phytoprostane concentration of carbonic maceration wine (CMW) $(131.7 \pm 2.3 \mathrm{ng} / \mathrm{mL})$ was significantly lower $(p>0.05)$.

The levels of individual phytoprostanes varied consistently among the different classes of phytoprostanes (Table 1). The $\mathrm{F}_{1}$-phytoprostane series class was generally the most abundant class $(p<0.05)$ found in all of the samples, Phytol being the most abundant compound $(436.6 \pm 7.9 \mathrm{ng} / \mathrm{mL})$. Likewise, a change in the proportion of the $\mathrm{F}_{1}$-phytoprostane series was observed in both aged wines (AW and HEW). In CMM, AM, HEM, and CMW, Phytol was found at a higher concentration $(p<0.05)(32.7 \pm 1.8,13.5 \pm 0.1,149.8 \pm 1.8$, and $90 \pm 0.9$ $\mathrm{ng} / \mathrm{mL}$, respectively) than the sum of Phyto $2+3(6.8 \pm 0.3,4.5$ $\pm 0.1,50.1 \pm 0.1$, and $19.9 \pm 0.4 \mathrm{ng} / \mathrm{mL}$, respectively). However, in AW and HEW the opposite relationship was found: the sum of Phyto2+3 (133.8 \pm 2.2 and $124.9 \pm 1.7 \mathrm{ng} /$ $\mathrm{mL}$, respectively) exceeded the level of Phyto1 (76.9 \pm 0.7 and $73.6 \pm 2.4 \mathrm{ng} / \mathrm{mL}$, respectively). Therefore, transformations of the stereoisomers during the aging of wines could change the proportion of the $F_{1}$-phytoprostane series.

The $D_{1}$-phytoprostane series class was found primarily in HEM. Two epimeric compounds (Phyto4 $(25.1 \pm 2.1 \mathrm{ng} / \mathrm{mL}$ ) and Phyto5 $(200.4 \pm 11.1 \mathrm{ng} / \mathrm{mL}))$ were abundant in HEM. However, the level of Phyto 4 in the rest of the samples did not exceed $0.6 \mathrm{ng} / \mathrm{mL}$, whereas Phyto5 was also plentiful in CMW $(17.1 \pm 0.7 \mathrm{ng} / \mathrm{mL})$. Minor amounts were found in CMM and $\mathrm{AM}(8.7 \pm 0.4$ and $2.3 \pm 0.5 \mathrm{ng} / \mathrm{mL}$, respectively), with even lower values in the rest of the samples.

As commented above, the analytical conditions employed in the present study did not allow the separation of the different enantiomers. Therefore, enantiomers of both the 9-L- and 16B-phytoprostanes series of $\mathrm{B}_{1^{-}}$and $\mathrm{L}_{1^{-}}$phytoprostanes were quantitated together. Consequently, these two classes were

Table 1. Content of Individual Phytoprostanes Analyzed in Three Types of Musts and Wines ${ }^{a}$

\begin{tabular}{|c|c|c|c|c|c|c|c|}
\hline structure & phytoprostane & CMW & AW & HEW & CMM & $\mathrm{AM}$ & HEM \\
\hline Phyto1 & 9-F ${ }_{1 t}$-phytoprostane & $90.04 \pm 0.9$ & $76.9 \pm 0.7$ & $73.5 \pm 2.4$ & $32.7 \pm 1.8$ & $13.5 \pm 0.1$ & $149.8 \pm 1.8$ \\
\hline Phyto2+3 & $\begin{array}{l}\text { ent-16-epi-16- } \mathrm{F}_{1 \mathrm{t}} \text {-phytoprostane }+ \text { ent }-16-\mathrm{F}_{1 \mathrm{t}^{-}} \\
\text {phytoprostane }\end{array}$ & $19.9 \pm 0.3$ & $133.8 \pm 2.2$ & $124.9 \pm 1.7$ & $6.7 \pm 0.2$ & $4.5 \pm 0.08$ & $50.1 \pm 0.08$ \\
\hline Phyto4 & 9-epi-9-D $\mathrm{D}_{1 \mathrm{t}}$-phytoprostane & $0.4 \pm 0.02$ & $0.1 \pm 0.02$ & $0.09 \pm 0.005$ & $0.6 \pm 0.03$ & $0.1 \pm 0.06$ & $21.5 \pm 2.1$ \\
\hline Phyto5 & 9- $\mathrm{D}_{1 \mathrm{t}}$-phytoprostane & $17.1 \pm 0.7$ & $2.2 \pm 0.01$ & $1.2 \pm 0.01$ & $8.7 \pm 0.4$ & $2.3 \pm 0.5$ & $200.4 \pm 11.1$ \\
\hline Phyto6+7 & $\begin{array}{l}\text { 16- } \mathrm{B}_{1} \text {-phytoprostane }+ \text { ent- } 16-\mathrm{B}_{1^{-}} \\
\text {phytoprostane }\end{array}$ & $0.3 \pm 0.001$ & ND & ND & ND & ND & $2.5 \pm 0.1$ \\
\hline Phyto8+9 & $\begin{array}{l}\text { 9- } \mathrm{L}_{1} \text {-phytoprostane }+ \text { ent- } 9-\mathrm{L}_{1^{-}} \\
\text {phytoprostane }\end{array}$ & $3.8 \pm 0.2$ & ND & ND & ND & ND & $6.4 \pm 0.3$ \\
\hline
\end{tabular}

${ }^{a}$ Results are expressed in $\mathrm{ng} / \mathrm{mL} \pm \mathrm{SD}$. CMW/CMM, carbonic maceration wine/must; AW/AM, aged wine/must; HEW/HEM, high expression wine/must; ND, not detected. 
identified and quantitated as the sum of $9-\mathrm{L}_{1^{-}}+9-\mathrm{L}_{1}-$ ent $-16-\mathrm{B}_{1}$ phytoprostane and the sum of $16-\mathrm{B}_{1^{-}}+$ent-16- $\mathrm{B}_{1} 9-\mathrm{L}_{1^{-}}$phytoprostane, respectively. Finally, compounds from the $B_{1}$ and $\mathrm{L}_{1}$-phytoprostane classes (Phyto6+7 and Phyto8+9) were found in very low amounts. Only in CMW and HEM they were abundant enough to be quantitated, according to the limit of quantitation of the method developed by Collado-González et al. ${ }^{12}$ In fact, in these two samples, the sums of the concentrations of Phyto6+7 (2.8 $\pm 0.1 \mathrm{ng} / \mathrm{mL})$ and Phyto $8+9(10.3 \pm 0.5 \mathrm{ng} / \mathrm{mL})$ were not significant compared to the quantities found in the other phytoprostane classes $(p>$ $0.05)$.

The vinification process seems to modify the initial content of phytoprostanes in the must, because wines CMW and AW showed higher total phytoprostane concentrations than CMM and $\mathrm{AM}$ (their corresponding primary musts). The musts CMM $(48.7 \pm 2.4 \mathrm{ng} / \mathrm{mL})$ and AM $(20.4 \pm 0.7 \mathrm{ng} / \mathrm{mL})$ had lower concentrations $(p<0.05)$ of total phytoprostanes than their respective finished wines $(131.8 \pm 2.1$ and $213 \pm 2.9 \mathrm{ng} /$ $\mathrm{mL}$ for $\mathrm{CMW}$ and $\mathrm{AW}$, respectively). The wine aging process may be an important factor in the formation of phytoprostanes. The musts CMM and AM exhibited similar $(p>0.05)$ phytoprostane levels. Nevertheless, after the vinification process, the total phytoprostane concentration in CMW was lower than in AW. In the case of CMW, this concentration could have been a consequence of the carbonic maceration process (extraction) applied to the grapes and the consequent alcoholic and malolactic fermentation in stainless steel tanks. ${ }^{19}$ However, the vinification of AW could have been more oxidative, owing to the use of oak wood barrels for the aging procedure employed in the vinification. This could have released pro-oxidant compounds into the medium, in addition to promoting greater contact with oxygen. ${ }^{20}$ In wine, ROS can be produced by reduced transition metals ions such as copper or iron. Superoxide radical anions, hydroperoxyl radicals, or hydrogen peroxide could be responsible of the oxidation of ALA. $^{21}$ The vinification of AW included an aging process that was not included in the production of CMW. The oxidation processes during this vinification, besides the aging of the red wine, could have led to the production of reactive pro-oxidant molecules that oxidize ALA to phytoprostanes, explaining the difference in the final level of total phytoprostanes between CMW and AW.

By contrast, in the vinification process that yielded HEW from HEM, the primary must showed a total phytoprostane concentration that was $>2$-fold higher $(430.9 \pm 15.7 \mathrm{ng} / \mathrm{mL})$ than that of the finished wine $(199.8 \pm 4.2 \mathrm{ng} / \mathrm{mL})$. This reduction could be mainly attributable to the great loss of the 9series of the $\mathrm{D}_{1}$-phytoprostane class. It is important to highlight that the $\mathrm{D}_{1}$-phytoprostane class is the only one studied that is not a terminal compound (end product) in the nonenzymatic lipid peroxidation. In this sense, the decline of the total phytoprostane content may be explained by the rearrangement into $\mathrm{J}_{1}$ - and $\mathrm{dJ}_{1}$-phytoprostanes, by a dehydration reaction, of the Phyto5, present in large amounts in HEM (200.4 \pm 11.2 $\mathrm{ng} / \mathrm{mL}$ ). This probably occurred during the vinification process of HEW. Because pro-oxidant compounds are present during the vinification process, the stability of intermediate phytoprostanes is uncertain. ${ }^{3,22}$ The oxidizing conditions during the vinification process probably led to the oxidation of ALA and, thus, the formation of $\mathrm{D}_{1}$-phytoprostanes. The $\mathrm{D}_{1}$-phytoprostanes may have been oxidized to $\mathrm{J}_{1}$ - and $\mathrm{dJ}_{1}$-phytoprostanes, but this could not be investigated as there are no authentic markers available for these compounds.

To our knowledge, no papers that describe the phytoprostane content in wine or must have been published. Nevertheless, a few plant matrices have been investigated to report the phytoprostane occurrence. ${ }^{3}$ Tobacco, Arabidopsis thaliana, Crotalaria cobalticola, Eschscholzia californica, and birch pollen have shown the presence of phytoprostanes. Birch pollen had the highest phytoprostane concentration of all these matrices $(32 \mu \mathrm{g} / \mathrm{g}) .^{23}$ Consequently, the selection of the plant tissue analyzed is very important, because ROS are not produced equally throughout all of the structures of the plant. In fact, green tissues are the most likely producers of ROS, because of the singlet oxygen formed in the chloroplast during photosynthesis, leading to an increase in the number of peroxidation products. ${ }^{22}$ Savchenko et al. ${ }^{24}$ reported that the total amount of phytoprostanes in photosynthetic tissue is 10 times higher than in roots. In this sense, depending on the tissue studied, phytoprostane levels might vary extensively. Few researchers have reported phytoprostane contents in foods. Durand et al. ${ }^{22}$ described high amounts of phytoprostanes in tomato leaves, $\mathrm{F}_{1^{-}}, \mathrm{E}_{1^{-}}$, and $\mathrm{d}-\mathrm{J}_{1}$-phytoprostanes being the most abundant. The level of phytoprostanes in almonds and olive/sunflower oil has been reported to range from 4.0 to $23.8 \mathrm{ng} / 100 \mathrm{~g}$. $^{12,25,26}$

Researchers have highlighted the importance of phytoprostanes as bioactive lipid derivatives, not only in plant matrices but also in mammalian systems. ${ }^{27}$ Phytoprostanes, derived from a nonenzymatic oxidation reaction, are believed to exert beneficial effects in the organism. ${ }^{3,5,27}$ Due to their similarities to different prostaglandins, they could mimic the effects of the latter on the organism. ${ }^{4,22,28}$ In the present survey, $F_{1}$ phytoprostanes were the most abundant class of phytoprostanes in all of the samples studied $(436.6 \pm 7.9 \mathrm{ng} / \mathrm{mL}$ for 9$\mathrm{F}_{1 \mathrm{t}}$-phytoprostane and $340.1 \pm 4.8 \mathrm{ng} / \mathrm{mL}$ for ent-16-epi-16- $\mathrm{F}_{1 \mathrm{t}^{-}}$ phytoprostane). These phytoprostanes can regulate inflammatory responses in dendritic cells. ${ }^{23}$ Karg et al. ${ }^{5}$ reported that $A_{1}$ and $B_{1}$-phytoprostanes inhibited the release of nitric oxide in lipopolysaccharide-stimulated RAW264.7 macrophages. Thus, cardiovascular diseases could be ameliorated by the effects of phytoprostanes. In fact, Barden et al. ${ }^{28}$ related the intake of $F_{1}$ phytoprostanes to protective effects on the cardiovascular system.

The importance of the intake of phytoprostanes could be related to neuroprotective effects, too. Minghetti et al. ${ }^{27}$ showed that $B_{1}$-phytoprostanes were biologically active in experimental models of immature cells of the central nervous system, exhibiting neuroprotective effects against oxidant injury induced by hydrogen peroxide and promoting myelination through mechanisms that involve activation of the peroxisome proliferator-activated receptor (PPAR) $-\gamma$.

Bioavailability of phytoprostanes has also been demonstrated in vivo with healthy humans. Barden et al. ${ }^{28}$ examined the effect of flaxseed oil, containing arachidonic acid; they examined the effect of a diet supplemented with flaxseed oil on $F_{1}$ phytoprostane and $\mathrm{F}_{2}$-isoprostane concentrations in the urine and plasma of healthy men. Both the plasma and urine analyses confirmed the absorption of phytoprostanes by the intestinal tract. The esterified and nonesterified phytoprostane levels before intake of flaxseed oil were higher in plasma than in urine. Not only oil has been demonstrated to contain phytoprostanes, parenteral nutrition ${ }^{5}$ has also shown a significant content of these metabolites $(0.09-99 \mathrm{mg} / \mathrm{L})$. 
Assuming these possible beneficial effects, phytoprostanes would have an important impact on the Mediterranean diet, due to the wide consumption of wine around the world. The $\mathrm{F}_{1}$-phytoprostane concentrations found in the red wines and musts and the suggested beneficial effects on the organism make their contribution relevant in the beneficial effects of the Mediterranean diet. However, further studies seem to be necessary to understand the physiological relevance of phytoprostanes in general and of $F_{1}$-phytoprostanes in particular, for example, their role in preventing myocardial infarction or heart disease.

To the best of our knowledge, this is the first paper describing the presence of phytoprostanes in wine or must. The results showed the $F_{1}$-phytoprostanes as the most abundant class for all samples. Likewise, $D_{1}$-phytoprostanes were present in musts in large quantities, especially in HEM. Vinification and aging procedures may influence and change the initial phytoprostane profile, favoring the formation of pro-oxidant species. Further studies are needed to elucidate the development of phytoprostanes during wine production.

With the possible beneficial effects of phytoprostanes in the cardiovascular system and the high concentrations observed in wines and musts taken into account, phytoprostanes could be an important factor in the cardioprotective or cerebrovascular effects of red wine and the Mediterranean diet, due to their possible anti-inflammatory effects. However, further clinical trials with humans and with animal models are necessary to elucidate how phytoprostanes could improve the cardiovascular system or exert neuroprotective effects.

\section{AUTHOR INFORMATION}

\section{Corresponding Author}

*(A.G.-I.) Phone: +34 968396363. Fax: +34 968396213. Email: angelgil@cebas.csic.es.

\section{Funding}

We are grateful to the UCAM for its support during the development of the assay for the study. The study received financial support from national funding agencies through Project AGL2011-23690 (CICYT). S.M. is grateful to the CICYT for a research contract (AGL2011-23690).

\section{Notes}

The authors declare no competing financial interest.

\section{ACKNOWLEDGMENTS}

We thank Pablo Rodríguez and David Walker, expert reviewers of the written English.

\section{REFERENCES}

(1) Guerrero, R. F.; García-Parrilla, M. C.; Puertas, B.; Cantos-Villar, E. Wine; resveratrol and health: a review. Nat. Prod. Commun. 2009, 4 (5), 635-658.

(2) Magder, S. Reactive oxygen species: toxic molecules or spark of life? Crit. Care 2006, 10 (1), 208.

(3) Durand, T.; Bultel-Poncé, V.; Guy, A.; El Fangour, S.; Rossi, J. C.; Galano, J. M. Isoprostanes and phytoprostanes: bioactive lipids. Biochimie 2011, 93 (1), 52-60.

(4) Imbusch, R.; Mueller, M. J. Formation of isoprostane f2-like compounds (phytoprostanes f1) from $\alpha$-linolenic acid in plants. Free Radical Biol. Med. 2000, 28 (5), 720-726.

(5) Karg, K.; Dirsch, V. M.; Vollmar, A. M.; Cracowski, J. L.; Laporte, F.; Mueller, M. J. Biologically active oxidized lipids (phytoprostanes) in the plant diet and parenteral lipid nutrition. Free Radical Res. 2007, 41 (1), 25-37.
(6) Thoma, I.; Loeffler, C.; Sinha, A. K.; Gupta, M.; Krischke, M.; Steffan, B.; Roitsch, T.; Mueller, M. J. Cyclopentenone isoprostanes induced by reactive oxygen species trigger defense gene activation and phytoalexin accumulation in plants. Plant J. 2003, 34 (3), 363-375.

(7) Loeffler, C.; Berger, S.; Guy, A.; Durand, T.; Bringmann, G.;

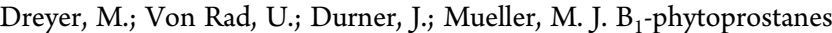
trigger plant defense and detoxification responses. Plant Physiol. 2005, 137 (1), 328-340.

(8) Mueller, S.; Hilbert, B.; Dueckershoff, K.; Roitsch, T.; Krischke, M.; Mueller, M. J.; Berger, S. General detoxification and stress responses are mediated by oxidized lipids through tga transcription factors in arabidopsis. Plant Cell 2008, 20 (3), 768-785.

(9) Traidl-Hoffmann, C.; Mariani, V.; Hochrein, H.; Karg, K.; Wagner, H.; Ring, J.; Mueller, M. J.; Jakob, T.; Behrendt, H. Pollenassociated phytoprostanes inhibit dendritic cell interleukin-12 production and augment $\mathrm{t}$ helper type 2 cell polarization. J. Exp. Med. 2005, 201 (4), 627-636.

(10) Mariani, V.; Gilles, S.; Jakob, T.; Thiel, M.; Mueller, M. J.; Ring, J.; Behrendt, H.; Traidl-Hoffmann, C. Immunomodulatory mediators from pollen enhance the migratory capacity of dendritic cells and license them for th2 attraction. J. Immunol. 2007, 178 (12), 76237631.

(11) Gutermuth, J.; Bewersdorff, M.; Traidl-Hoffmann, C.; Ring, J.; Mueller, M. J.; Behrendt, H.; Jakob, T. Immunomodulatory effects of aqueous birch pollen extracts and phytoprostanes on primary immune responses in vivo. J. Allergy Clin. Immunol. 2007, 120 (2), 293-299.

(12) Collado-González, J.; Pérez-López, D.; Memmi, H.; Gijón, M. C.; Medina, S.; Durand, T.; Guy, A.; Galano, J. M.; Ferreres, F.; Torrecillas, A.; Gil-Izquierdo, A. Water deficit during pit hardening enhances phytoprostanes content; a plant biomarker of oxidative stress; in extra virgin olive oil. J. Agric. Food Chem. 2015, 63 (14), 3784-3792.

(13) El Fangour, S.; Guy, A.; Vidal, J. P.; Rossi, J. C.; Durand, T. A flexible synthesis of the phytoprostanes $\mathrm{B}_{1}$ types I and II. J. Org. Chem. 2005, 70 (3), 989-997.

(14) El Fangour, S.; Guy, A.; Despres, V.; Vidal, J. P.; Rossi, J. C.; Durand, T. Total synthesis of the eight diastereomers of the syn-antisyn phytoprostanes $\mathrm{F}_{1}$ types I and II. J. Org. Chem. 2004, 69 (7), $2498-2503$.

(15) Durand, T.; Guy, A.; Henry, O.; Roland, A.; Bernad, S.; El Fangour, S.; Vidal, J. P.; Rossi, J. C. Total syntheses of iso-; neuro- and phytoprostanes: new insight in lipid chemistry. Chem. Phys. Lipids 2004, 128 (1-2), 15-33.

(16) Pinot, E.; Guy, A.; Fournial, A.; Balas, L.; Rossi, J. C.; Durand, T. Total synthesis of the four enantiomerically pure diasteroisomers of the phytoprostanes $\mathrm{E}_{1}$ type $\mathrm{II}$ and of the $15-\mathrm{E}_{2 \mathrm{t}}$-isoprostanes. J. Org. Chem. 2008, 73 (8), 3063-3069.

(17) Medina, S.; Domínguez-Perles, R.; Gil, J. I.; Ferreres, F.; GarcíaViguera, C.; Martínez-Sanz, J. M.; Gil-Izquierdo, A. A ultra-pressure liquid chromatography/triple quadrupole tandem mass spectrometry method for the analysis of 13 eicosanoids in human urine and quantitative $24 \mathrm{~h}$ values in healthy volunteers in a controlled constant diet. Rapid Commun. Mass Spectrom. 2012, 26 (10), 1249-1257.

(18) Soleas, G. J.; Diamandis, E. P.; Goldberg, D. M. Wine as a biological fluid: history; production; and role in disease prevention. J. Clin. Lab. Anal. 1997, 11 (5), 287-313.

(19) Tesniere, C.; Flanzy, C. Adv. Food Nutr. Res. 2011, 63, 1-15.

(20) Jackson, R. Wine Science, 3rd ed.; Academic Press: Burlington, MA, USA, 200810.1016/B987-0-12-373646-8.50020-2.

(21) Oliveira, C. M.; Ferreira, A. C. S.; De Freitas, V.; Silva, A. M. S. Oxidation mechanisms occurring in wines. Food Res. Int. 2011, 44 (5), $1115-1126$.

(22) Durand, T.; Bultel-Poncé, V.; Guy, A.; Berger, S.; Mueller, M. J.; Galano, J. M. New bioactive oxylipins formed by non-enzymatic freeradical-catalyzed pathways: the phytoprostanes. Lipids 2009, 44 (10), $875-888$.

(23) Gilles, S.; Mariani, V.; Bryce, M.; Mueller, M. J.; Ring, J.; Jakob, T.; Pastore, S.; Behrendt, H.; Traidl-Hoffmann, C. Pollen-drived $\mathrm{E}_{1}$ 
Pytoprostanes signal via PPAR- $\gamma$ and NF- $\kappa$ B-dependent mechanisms. $J$. Immunol. 2009, 182 (11), 6653-6658.

(24) Savchenko, T. V.; Zastrijnaja, O. M.; Klimov, V. V. Oxylipins and plant abiotic stress resistance. Biochemistry (Moscow) 2014, 79 (4), $362-375$.

(25) Collado-González, J.; Durand, T.; Ferreres, F.; Medina, S.; Torrecillas, A.; Gil-Izquierdo, A. Phytoprostanes. Lipid Technol. 2015, 27 (6), 127-130.

(26) Carrasco-Del Amor, A. M.; Collado-Gonzalez, J.; Aguayo, E.; Guy, A.; Galano, J. M.; Durand, T.; Gil-Izquierdo, A. Phytoprostanes in almonds: Identification; quantitation; and impact of cultivar and type of cultivation. RSC Adv. 2015, 5 (63), 51233-51241.

(27) Minghetti, L.; Salvi, R.; Lavinia Salvatori, M.; Antonietta Ajmone-Cat, M.; De Nuccio, C.; Visentin, S.; Bultel-Poncé, V.; Oger, C.; Guy, A.; Galano, J. M.; Greco, A.; Bernardo, A.; Durand, T. Nonenzymatic oxygenated metabolites of $\alpha$-linolenic acid $\mathrm{B}_{1^{-}}$and $\mathrm{L}_{1^{-}}$ phytoprostanes protect immature neurons from oxidant injury and promote differentiation of oligodendrocyte progenitors through ppar- $\gamma$ activation. Free Radical Biol. Med. 2014, 73, 41-50.

(28) Barden, A. E.; Croft, K. D.; Durand, T.; Guy, A.; Mueller, M. J.; Mori, T. A. Flaxseed oil supplementation increases plasma $\mathrm{F}_{1}$ phytoprostanes in healthy men. J. Nutr. 2009, 139 (10), 1890-1895. 